Hydrol. Earth Syst. Sci., 17, 1021-1034, 2013

www.hydrol-earth-syst-sci.net/17/1021/2013/

doi:10.5194/hess-17-1021-2013

(C) Author(s) 2013. CC Attribution 3.0 License.

\title{
Geomorphology-based index for detecting minimal flood stages in arid alluvial streams
}

\author{
E. Shamir ${ }^{1}$, L. Ben-Moshe' ${ }^{2}$, A. Ronen ${ }^{3}$, T. Grodek ${ }^{2}$, Y. Enzel ${ }^{3}$, K. P. Georgakakos ${ }^{1,4}$, and E. Morin ${ }^{2}$ \\ ${ }^{1}$ Hydrologic Research Center, San Diego, California, USA \\ ${ }^{2}$ The Hebrew University of Jerusalem, Department of Geography Mount Scopus, Jerusalem, 91905, Israel \\ ${ }^{3}$ The Hebrew University of Jerusalem, The Fredy \& Nadine Herrmann Institute of Earth Sciences, \\ Givat Ram Jerusalem 91904, Israel \\ ${ }^{4}$ Scripps Institution of Oceanography, University of California San Diego, La Jolla California, USA
}

Correspondence to: E. Shamir (eshamir@hrc-lab.org)

Received: 29 September 2012 - Published in Hydrol. Earth Syst. Sci. Discuss.: 5 November 2012

Revised: 14 February 2013 - Accepted: 19 February 2013 - Published: 7 March 2013

\begin{abstract}
Identification of a geomorphic index to represent lower thresholds for minor flows in ephemeral, alluvial streams in arid environments is an essential step as a precursor for reliable flash flood hazard estimations and establishing flood warning systems. An index, termed Alluvial wadi Flood Incipient Geomorphologic Index (AFIG), is presented. Analysis of data from an extensive field survey in the arid ephemeral streams in southern and eastern Israel was conducted to investigate the AFIG and the control over its value across the region. During the survey we identified distinguishable flow marks in the lower parts of streams' banks, such as niches, vegetation line, and change in bank material, which are indicative of low flows. The cross-sectional characteristics of the AFIG were studied in relationship with contributing drainage basin characteristics such as lithology, topography, and precipitation. Drainage area and hardness of the exposed lithology (presented as a basin-wide index) are the preferred descriptors to be used in estimating a specific AFIG in unsurveyed sites. Analyses of discharge records from seven hydrometric stations indicate that the recurrence interval of the determined AFIG is equal to or more frequent than $0.5 \mathrm{yr}$.
\end{abstract}

\section{Introduction}

In mildly sloped humid regions, which are entrenched with perennial streams, the economic damage and fatalities from floods are caused mainly by water overtopping banks of rivers to cause floodplain inundation. For that reason, bankfull flow -i.e., a flow in which the water level in a stream or a river is at the top of its banks and further rise would result in inundation of the floodplain (Leopold, 1994) - often serves in temperate to humid areas as a geomorphic threshold in flood warning systems to indicate the incipience of minor flooding (e.g., Carpenter et al., 1999; Reed et al., 2002; Georgakakos, 2006; Shamir et al., 2013). The use of a geomorphic index for hydrologic application implies that this index can potentially be estimated for unsurveyed and/or ungauged locations from empirical regional relationships that use upstream terrain and climatic characteristics as predictors (e.g., Leopold, 1994).

In ephemeral channels of arid environment, marks of bankfull flow are often difficult to identify (Graf, 1988; Richards, 1982). In addition, hazardous floods are often defined as existence of water in the commonly dry river channels regardless of the specific discharge or stage (Graf, 1988; Cooke et at., 1993; Tooth, 2000). The major economic damage and fatalities in arid regions are caused by short lived floods characterized by a fast, almost instantaneous, rising water stage (e.g., Schick and Sharon, 1974). In addition, in regions where ephemeral streams are predominant, vulnerable properties, assets, and activities are often located within the channel of the rivers.

An informal survey that was carried among operational response agencies in Israel that are required to respond to flood occurrences, concluded that a suitable flood warning system for the arid regions is expected to alert on all occasions in 
which flow is shown in the channels, regardless of its magnitude. These small flows, which are contained within the channel can either be, or quickly develop to be, hazardous flow events.

This study is motivated by the need to identify fieldbased geomorphologic marks of low flows in ephemeral arid streams that can be indicative of minor flash floods in arid ephemeral streams. These geomorphologic marks can potentially be estimated for ungauged and unsurveyed basins as low-flow indicators. In conjunction with hydrologic models, these marks provide a continuous and dynamic risk assessment that identifies the short-term hydrologic conditions that can lead to these flows given continuously changing antecedent conditions. Such a modeling framework provides a tool for forecasters to assess short-term forecasts and issue flash flood watches and warnings for specific locations (e.g., Georgakakos, 1987; Reed et al., 2002; Shamir et al., 2013).

The results of a comprehensive field survey conducted in the arid region of Israel are described. In this field survey we searched for an index termed an Alluvial wadi Flood Incipient Geomorphologic index (hereinafter AFIG) that can be used as a threshold index for flood inception in arid alluvial and ephemeral streams. Following the literature review and description of the geographic and climatic traits of the study region, the field survey and its results are described. We then present an assessment of the AFIG cross-sectional hydraulic properties with respect to various properties of the drainage area of the basins, and derive estimates of the AFIG recurrence intervals.

\section{Literature review}

Geomorphic indices are used in hydrologic applications based on the premise that the geomorphic catchment development is related to catchment and channel characteristics and therefore can be determined from GIS information for ungauged regions (Rodriguez-Iturbe and Valdes, 1979; Carpenter et al., 1999). Bankfull flow often serves as a conservative physical index for the initiation of flooding. Various studies reported large uncertainty and variability in the estimate of bankfull flow that stem from (a) existence of various field marks to identify the bankfull in a field survey (e.g., Williams, 1978; Gordon et al., 1992; Leopold, 1994), and (b) the variability and uncertainty in assessment of bankfull cross sections in various environments (e.g., Woodyer, 1968; Radecki-Pawlik, 2002; Carpenter et al., 2007; Navratil et al., 2006; Harman et al., 2008).

Using annual peak discharge series, Leopold et al. (1964) reported that the return period of bankfull flow is approximately 1 to 2 yr. This return period was later confirmed as reasonable a priori estimate although a wider range of estimates of return period have been reported (e.g., Harvey, 1969; Dury, 1973; Williams, 1978; Gomez et al., 2006; Schneider et al., 2011). Bankfull flow studies in arid and semiarid ephemeral streams reported various ranges of reoccurrence intervals: e.g., 1.1-1.8 yr in Arizona and New Mexico (Moody et al., 2003); 4-10 yr in New South Wales Australia (Pickup and Warner, 1976); 0.3-3.3 and 1.5-10.5 yr in Southern California (Carpenter, 2011; Coleman et al., 2005, respectively).

Another, often used, geomorphic indicator is the effective discharge, defined as the incremental discharge that transports the largest fraction of the annual total sediment load over many years. In their influential work, Wolman and Miller (1960) associated the recurrence interval (return period) with flow magnitude through a two-parameter power law function. They claimed that the product of the flow magnitude and the recurrence interval is an estimate of the channel geomorphic work accomplished by flows for various recurrence intervals. Wolman and Miller (1960) reported that most of the geomorphic work in the channel is attributed to moderate flow events and the effective discharge is between 1-2 yr return period, which is comparable to the recurrence interval of the bankfull flow. Their analysis was conducted for perennial streams in humid/sub-humid temperate climate regions with relatively low sediment entrainment threshold and well-vegetated catchments (Warritty, 1997). A significant body of research has followed that verifies and in some cases contests the assertion made by Wolman and Miller (1960) (e.g., Leopold et al., 1964; Kochel, 1988; Emmett and Wolman 2001; Phillips, 2002).

The convenient concept of bankfull flow and its association with effective discharge is often carried forward to arid environment with insufficient qualifications (Graf, 1988; Richards, 1982). In ephemeral desert streams, the identification of bankfull stage is a challenge because active channels are often much less defined than in wetter environments and the channels are often excessively broad, braided, or incised. Various alternative field marks, such as point bars, vegetation lines, change in depositional particle size, and terraces were proposed to indicate the morphological equivalent of bankfull (e.g., Moody et al., 2003; Lichvar and McColley, 2008; Morin et al., 2009a). Because systematic identification of these marks in field surveys of arid ephemeral channels is often challenging, the survey of the bankfull cross section may be considered rather subjective.

Anecdotal empirical studies reported that in desert streams the effective discharge is smaller than the bankfull discharge (e.g., Pickup and Warner, 1976). Moreover, the association of recurrence interval with effective discharge is climatically dependent and closely related to the discharge variability (Graf, 1988). Neff (1967) showed for example, that in an arid environment $60 \%$ of the sediment was transported by flows with recurrence intervals that are $>10 \mathrm{yr}$. Conversely, this percentage was only $10 \%$ of the sediment transported for flows $>10 \mathrm{yr}$ return period in humid environment. Baker (1977) reported that the channel geomorphic work is dependent on the underlying type of rock and vegetation 
cover, and in arid streams which typically have larger particles larger events are required for sediment transport.

Pickup and Rieger (1979) pointed out that simple relationships of morphologic variables as a function of discharge are valid for streams that reach steady state equilibrium (i.e., short-term fluctuation with a longer term constant mean value). Most streams however, are thought to follow a dynamic equilibrium that consists of three states: a landform changing event (e.g., a large flood), adjustment of form that follows that event (often referred to as healing period), and a period of steady state (Wolman and Gerson, 1978; Richards, 1982). The frequency and duration of these three states are much dependent on climate regime and local environment. In ephemeral arid climate, steady state conditions are rarely achieved and the healing periods are prolonged (Schick, 1974; Wolman and Gerson, 1978; Graf, 1988; Warritty, 1997). In addition, in arid regions the changes in channel width that are caused by landform changing events are much larger than in humid regions (Wolman and Gerson, 1978). Also in contrast to humid regions, the relative changes of channel width from a landform changing event are larger for basins that are smaller than $100 \mathrm{~km}^{2}$. This implies that in smaller arid basins, the widths of the channels have large variability (Wolman and Gerson, 1978).

Additional complicating factors with respect to bankfull flow and effective discharge that are common to arid ephemeral environment are (a) long bedrock channel reaches, which require large infrequent flows for transport of sediment and/or incision (e.g., Jensen, 2006); (b) variability and large uncertainties in the rate of transmission losses into alluvial beds in ephemeral streams cause discernible spatial variability and flow discontinuity, especially during relatively small flow events (e.g., Schick, 1988; Dunkerely and Brown, 1999; Goodrich et al., 1997; Schwartz, 2001; Dahan et al., 2007; Morin et al., 2009b); and (c) the sequence of flows in ephemeral steams often plays an important role in the channel geomorphic work (e.g., McEwen and Werritty, 1988). In addition, it is noted that channel banks in arid ephemeral environment are less stable as they lack vegetation and contain less clays that act as bank stabilizers (Schumm, 1961; Reid and Frostick, 1997).

Because of these unique characteristics of the ephemeral arid channels and their flash floods, the use of geomorphic indices such as bankfull flow and effective discharge for hydrological flood warning applications is thought to be inadequate.

\section{Study area}

The study was conducted in the southeastern part of Israel. Most of this region is classified as an arid or semiarid climate while some of the basin headwaters experience wetter conditions of a mountainous Mediterranean climate. Mean annual rainfall over the study region varies from

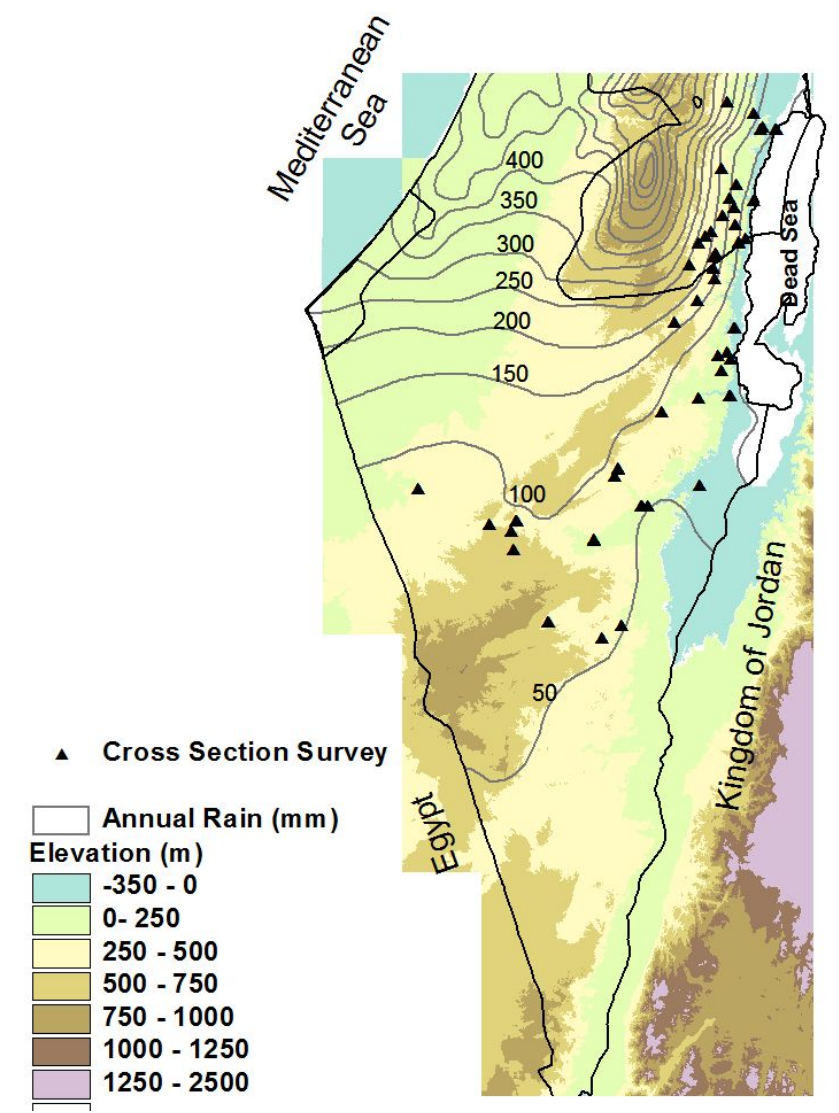

Fig. 1. A topographic map with the location of the surveyed cross sections. Annual climatic isohyets are also indicated.

450 to $30 \mathrm{~mm}$ (Fig. 1) and potential evaporation exceeds $2000 \mathrm{~mm} \mathrm{yr}^{-1}$ (Meirovich et al., 1998). The rainy season is October-May and the weather during June-September is hot and dry with only rare rain storms. Rainfall is highly variable across the area and can be either localized or widespread (e.g., Dayan and Sharon, 1980; Dayan and Abramski, 1983; Dayan and Morin, 2006). Runoff events in small catchments might be generated as a response to only $5 \mathrm{~mm}$ of rainfall, although in larger catchments, runoff is usually the consequence of at least $10-20 \mathrm{~mm}$ of rainfall (Meirovich et al., 1998; Greenbaum et al., 2006; Morin et al., 2009). Runoff generation is often from rainfall on exposed hard carbonate rocks and on shallow soils with low permeability (Yair and Kossovsky, 2002). The low permeability of the soils in some locations is attributed to the formation of a relatively thin surface crust either from microbiotic (e.g., Lange et al., 1992; Kidron et al., 2003), and/or mineral processes resulting from raindrop-surface interaction (Mualem and Assouline, 1991). A dominant hydrologic process that controls the streamflow generation is the loss of flow through infiltration into the channel alluvial bed and banks (i.e., transmission losses) (e.g., Shentsis et al., 1999). 
The short-term intense rain showers in relatively small basins (Sharon, 1972) together with (a) the regional low infiltration of exposed bedrock and sealing surfaces, and (b) the relatively steep terrain promote the development of flash floods. These floods carry sediment load that is much larger than a comparable flow event in a humid perennial environment (e.g., Laronne and Reid, 1993; Ben David-Novak et al., 2004).

These floods are characterized by high instantaneous discharges that can damage properties and pose a serious threat to human life. Kahana et al. (2002) reported that in the Negev Desert between 1965 and 1994, 52 major flash floods (recurrence interval $>5 \mathrm{yr}$ ) were recorded, with 0 to 6 events occurring in a given year.

\section{Field survey}

During February-September 2010, a geomorphic field survey was conducted in ephemeral channels in the Judean and Negev deserts, Israel. The survey focused on identifying marks for low water flows that can be used to develop the AFIG and surveying their cross sectional characteristics. During the survey a total of 75 sites were visited. These sites were identified based on a pre-survey GIS analysis. Forty-six sites that met the following criteria were found suitable for a detailed field survey: (a) existence of alluvial channel (except for two sites where bedrock channel were surveyed); (b) low water marks were identifiable; (c) relative homogeneity of channel geometry along the reach existed; and (d) the channels did not have low shoals that divide and braid the alluvial channels.

Three types of low flow marks were identified in the alluvial channels (Fig. 2):

1. The lowest vegetation line on the banks.

2. A natural scour impressed on the lower bank or a vertical face at the lower part of the banks.

3. A discernible change in gravel (mainly pebble) size on the banks.

The heights of the above low water marks above the channel bed were often slightly different in opposite banks probably due to local, sub-reach hydraulic conditions that are difficult to discern. In addition, they could have been formed by deeper local flows or by a relatively large and recent regional event (Graf, 1988). Irrespective of the inherent sources of uncertainty it was reassuring to find that these marks were identified in 42 out of the 46 reaches surveyed and in most of these they were consistently situated at $15-46 \mathrm{~cm}$ above the thalweg.

At each of the sites, 3 to 4 cross sections were surveyed, preferably at equal distance, depending on the locations of the most apparent low flow marks. Depending on the characteristic channel width, the length of the measured reaches
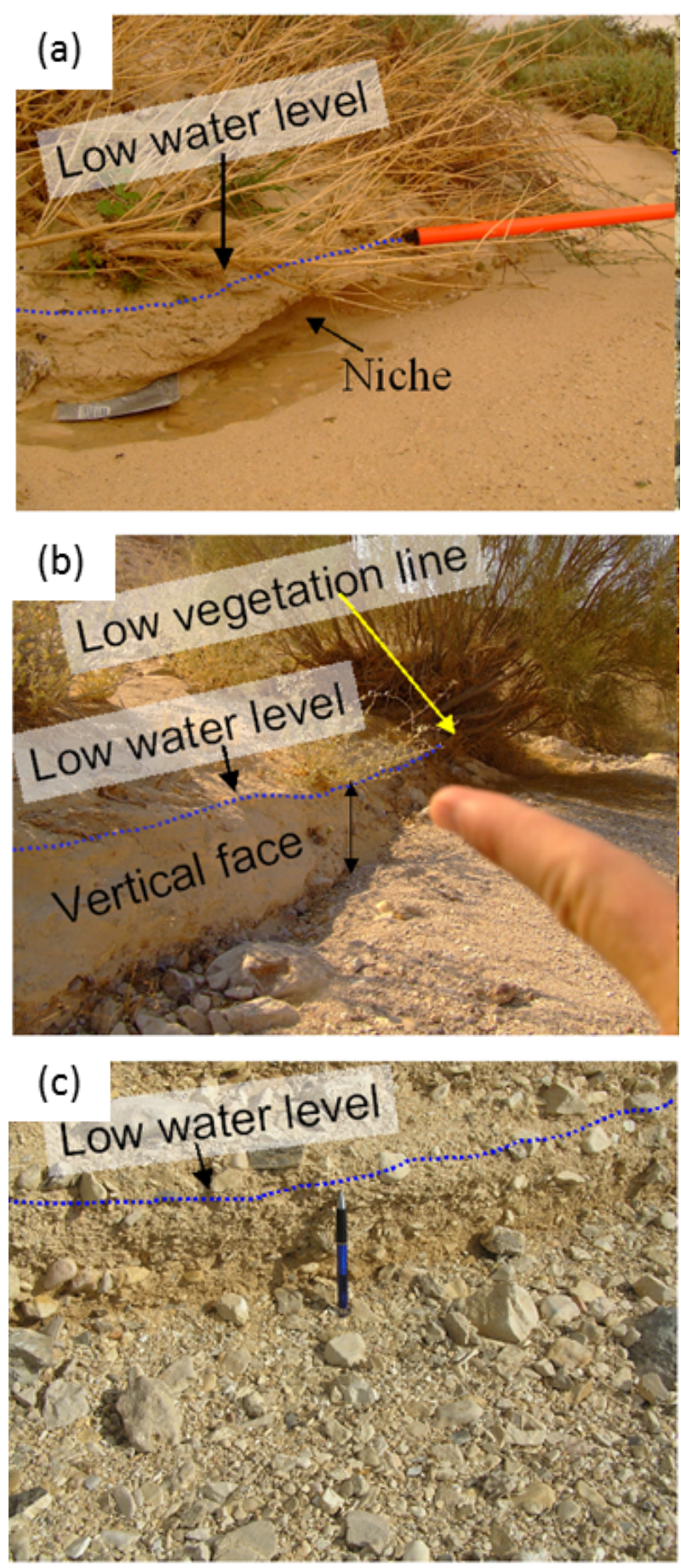

Fig. 2. Three types of low water marks that were identified in the alluvial channels: (a) a scour impressed on the lower bank (niche), (b) lowest vegetation line, and (c) change in pebble size.

from the downstream to upstream cross sections ranges from 30 to $100 \mathrm{~m}$. Figure 3 is a schematic diagram of a typical surveyed cross section and its marks. Low water marks were identified on both channel banks. 


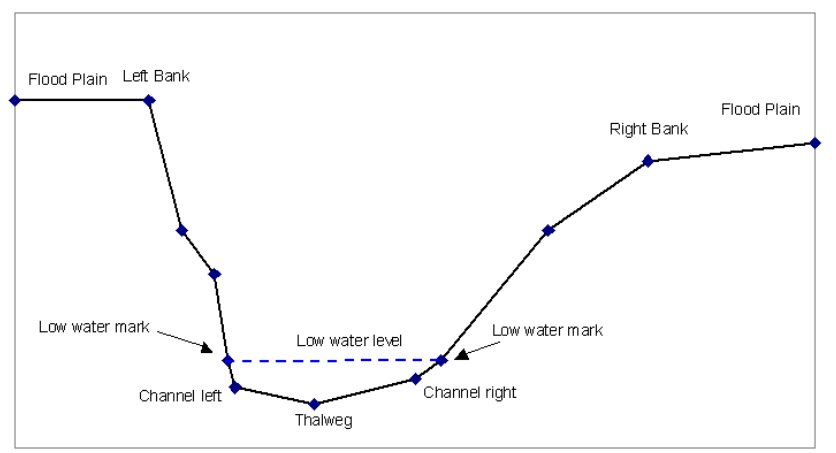

Fig. 3. Schematic diagram for a survey of a typical cross section.

Channel slope was obtained from the average of minimum and maximum gradients of the thawleg along the reach. For each site, the Manning roughness coefficient was estimated based on grain size, grain size variability, existence of shoals and other obstructions (Chow, 1959; Phillips and Tadayon, 2006). Examples of Manning roughness coefficients typical for the study area are seen in Fig. 4.

\section{Discharge estimate at the AFIG}

The discharge rate associated with the AFIG cross sectional data was estimated using the HEC-RAS software package (US Army Corps of Engineers, 2005). HEC-RAS is a steady and unsteady flow routing package based on the onedimensional energy equation. Following a comprehensive sensitivity analysis, the flows at the low flow marks were simulated as steady sub-critical flows, with a downstream normal depth boundary condition which was estimated by the actual channel slope as determined from the field survey.

The discharge estimation procedure using HEC-RAS software included the following tasks: (a) the determination of water-surface profiles associated with a series of preassigned discharge values; (b) comparison of the resulting water level profiles and the observed AFIG levels at the two uppermost cross sections of the reach (i.e., away from the downstream boundary conditions); and (c) identifying the discharges that follow the AFIG and additional iterations to narrow the range of discharge values associated with the AFIG until a good match of water levels was obtained. The same iterative procedure was carried out using Manning roughness coefficients that are $\pm 10 \%$ of the initial value to derive an uncertainty estimate that is associated with the selection of Manning coefficients and water level matching. The $20 \%$ uncertainty range that was assigned to the Manning coefficients is thought to be reasonable given the range of coefficients in this study (0.025-0.045) (US Army Corps of Engineers, 1986) and the large variability in the channel bed formation (as can be seen in Fig. 4). The derived AFIG discharge values and other hydraulic parameters for

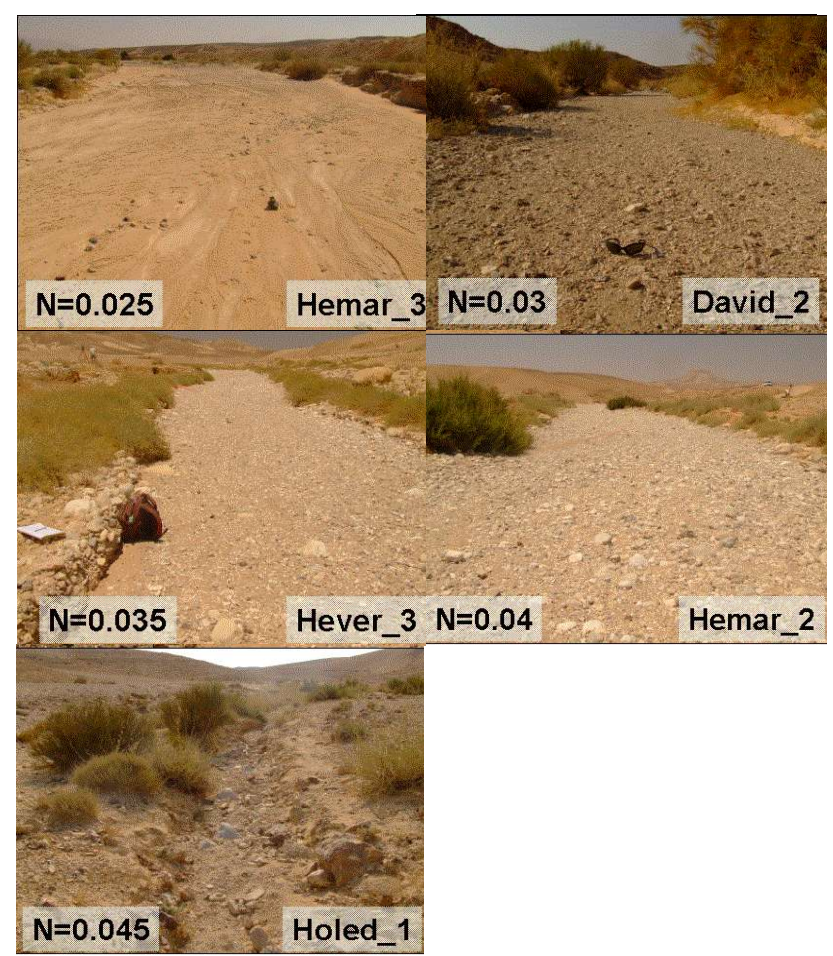

Fig. 4. Examples for Manning coefficients $(N)$ in typical cross sections from the study area. See Tables A1 and A2 for the properties of these cross section locations.

the uppermost cross section for all the sampling locations are provided in Table A2.

The distributions of the different hydraulic parameters are presented in Fig. 5. The water depth that is associated with the AFIG discharge ranges between 10 and $67 \mathrm{~cm}$ with an average of $29 \mathrm{~cm}$ and a standard deviation of $12 \mathrm{~cm}$. The largest water depth values and top width values are for the two largest catchments in the dataset $\left(>1000 \mathrm{~km}^{2}\right)$. Mean cross-section velocity for these low flows lies between 0.2 to $2.2 \mathrm{~m} \mathrm{~s}^{-1}$. Again, the two largest values were obtained for the two largest catchments. The relatively high velocities are due to the effect of the hydraulic radius, while slopes and Manning coefficients for these catchments were moderate. The distribution of the AFIG discharge values is positively skewed and the two highest values correspond to the large catchments due to their relatively large wetted area and mean velocity. The effect of catchment area on the AFIG discharge is further considered in Sect. 7.

The uncertainty range (minimum-maximum) around the estimated AFIG discharge is shown in Fig. 6 as a function of the cross-sectional drainage area. As explained above, this is the range of discharge values that represents the uncertainty associated with the water level estimate and the Manning coefficients. The uncertainty ranges are on average $0.6 \mathrm{~m}^{3} \mathrm{~s}^{-1}$ with a maximum value of $6 \mathrm{~m}^{3} \mathrm{~s}^{-1}$. Although uncertainty in some cases is quite a substantial percent of the estimated 

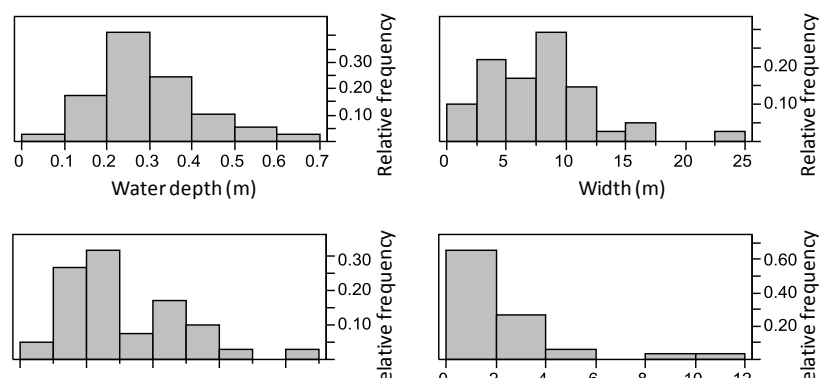

Mean velocity $(\mathrm{m} / \mathrm{s})$
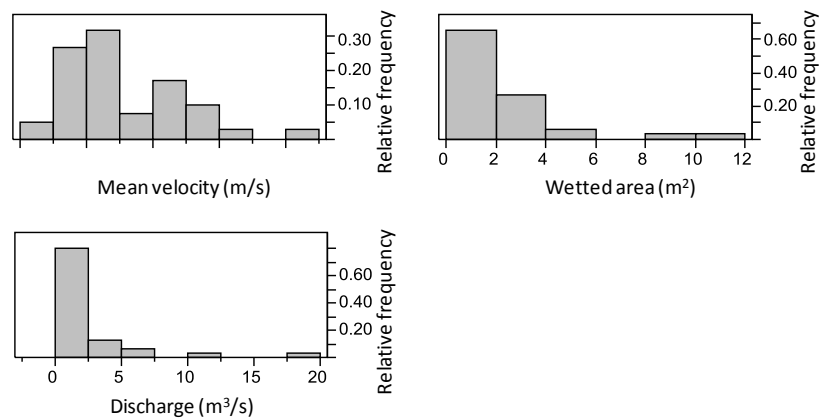

Fig. 5. Distribution of the AFIG hydraulic characteristics.

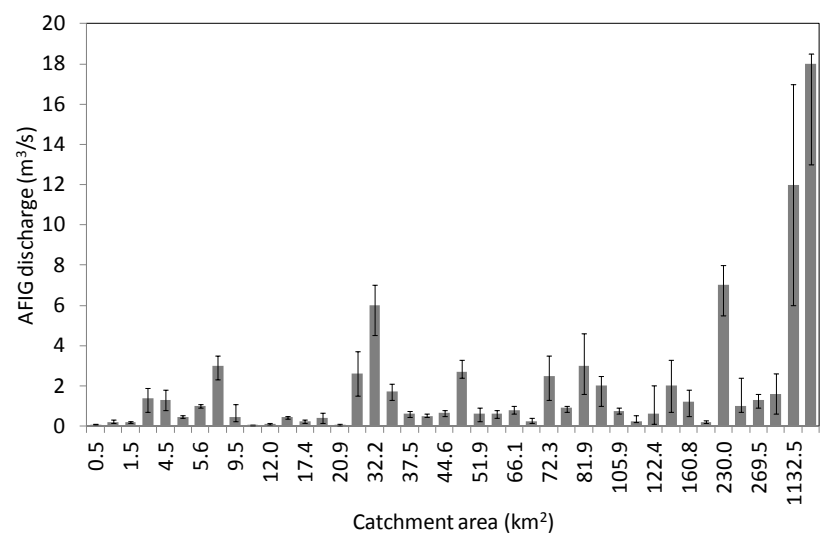

Fig. 6. Estimated AFIG discharge $\left(\mathrm{m}^{3} \mathrm{~s}^{-1}\right)$. Error bars represent uncertainty estimate that is associated with water level matching and Manning coefficients.

discharge (as high as $233 \%$ ), it is generally within a reasonable range of field-based discharge calculations ( $41 \%$ of the estimated discharge on average).

\section{GIS analysis of basin characteristics}

Various drainage basin characteristics were determined for the surveyed reaches by analyzing the following GIS layers: $25 \mathrm{~m}$ digital elevation model, lithologic map, and annual precipitation. For each survey site the following variables were estimated (Table A1):

$\mathrm{P} 1$ - Drainage area $\left(\mathrm{km}^{2}\right)$.

P2 - Rainfall index (Ben Moshe et al., 2008): mean annual volume of rain over the drainage area $\left(\mathrm{m}^{3} \mathrm{yr}^{-1}\right)$ contributing to the specific site.
Table 1. Derivation of softness and permeability indices from lithological classes.

\begin{tabular}{lll}
\hline Lithology & $\begin{array}{l}\text { Softness } \\
\text { Index }\end{array}$ & $\begin{array}{l}\text { Permeability } \\
\text { Index }\end{array}$ \\
\hline Unconsolidated Conglomerate & 1 & 3 \\
Clay & 1 & 1 \\
Marl & 1 & 1 \\
Sand & 1 & 3 \\
Chalk & 2 & 1 \\
Unconsolidated Sandstone & 2 & 2 \\
Chalk and limestone & 3 & 2 \\
Dolomite & 4 & 3 \\
Limestone & 4 & 3 \\
Gypsum & 4 & 1 \\
\hline
\end{tabular}

P3 - Specific rainfall index: mean annual areal rainfall over the drainage basin $\left(\mathrm{mm} \mathrm{yr}^{-1}\right)$.

P4 - Average relief of the drainage area $(\mathrm{m})$ estimated by averaging the relief of all the DEM cells.

P5 - Maximum relief difference in the drainage area (m).

P6 - Basin averaged softness and resistance to erosion.

P7 - Basin average permeability rate.

Both the softness and permeability indices were calculated as a weighted area index using the categorical classification of the exposed lithological GIS map (Table 1). The lithology classes were assigned four softness categories that range from softest and least resistant to hardest and most resistant. In this mostly barren landscape with large areas of exposed bedrock the erosion rate, runoff generation and sediment yield are associated with the lithological softness (Alexandrov et al., 2003). The permeability was characterized as three categories of low, medium, and high permeability rates. Basin permeability of the upper strata has a major role in runoff generation during rainfall event (Yair and Enzel, 1987). It has a strong association with runoff coefficient, and in arid environment, with exposed bedrock and relatively ubiquitous shallow soils, it is highly dependent on the geology and lithology (e.g., Meirovich et al., 1998). Because the categorical P6 and P7 descriptors describe basin characteristics that are relevant to the AFIG discharge they were used herein as continuous predictors.

The Pearson cross correlation coefficients $(R)$ among the seven descriptors are presented in Table 2. The asterisks in this table indicate correlation coefficient values that are significantly different than zero based on a Student's $t$ distribution test $(p<0.05)$. Basin drainage area is highly correlated with the rainfall index (0.88) and the maximum relief difference in the drainage area (0.67) (Table 2). The specific rainfall index (P3) is highly correlated with the average 
Table 2. Pearson cross correlation among the basins' descriptors.

\begin{tabular}{rrrrrrr}
\hline & P1 & P2 & P3 & P4 & P5 & P6 \\
\hline P2 & $0.88^{*}$ & & & & & \\
P3 & -0.18 & 0.21 & & & & \\
P4 & -0.11 & 0.17 & $0.68^{*}$ & & & \\
P5 & $0.67^{*}$ & $0.78^{*}$ & 0.09 & 0.22 & & \\
P6 & -0.01 & 0.14 & 0.30 & $0.33^{*}$ & -0.08 & \\
P7 & 0.14 & 0.26 & 0.27 & 0.15 & 0.13 & $0.75^{*}$ \\
\hline
\end{tabular}

* Correlation coefficient significantly different than zero correlation $(p<0.05)$.
Table 3. Pearson cross correlation between basin descriptors and cross sectional hydraulic parameters based on the calibration dataset.

\begin{tabular}{rrrrrrr}
\hline & Discharge & $\begin{array}{r}\text { Water } \\
\text { depth }\end{array}$ & $\begin{array}{r}\text { Top } \\
\text { width }\end{array}$ & $\begin{array}{r}\text { Mean } \\
\text { velocity }\end{array}$ & $\begin{array}{r}\text { Hydraulic } \\
\text { depth }\end{array}$ & $\begin{array}{r}\text { Wetted } \\
\text { perimeter }\end{array}$ \\
\hline P1 & $0.71^{*}$ & $0.48^{*}$ & $0.78^{*}$ & 0.11 & $0.45^{*}$ & $0.78^{*}$ \\
P2 & $0.60^{*}$ & $0.48^{*}$ & $0.73^{*}$ & 0.06 & $0.47^{*}$ & $0.73^{*}$ \\
P3 & -0.09 & 0.06 & -0.11 & 0.03 & 0.12 & -0.10 \\
P4 & 0.01 & 0.01 & 0.04 & 0.01 & 0.12 & 0.04 \\
P5 & 0.35 & 0.30 & $0.64^{*}$ & -0.13 & 0.26 & $0.64^{*}$ \\
P6 & 0.27 & $0.50^{*}$ & 0.33 & 0.25 & $0.50^{*}$ & 0.34 \\
P7 & 0.33 & $0.50^{*}$ & $0.45^{*}$ & 0.21 & $0.44^{*}$ & $0.45^{*}$ \\
\hline
\end{tabular}

* Correlation coefficient significantly different than zero correlation $(p<0.05)$.

\section{$7 \quad$ Regression analysis} ity indices are also highly correlated (0.75). The correlation of the drainage area with the rainfall and elevation gradient is attributed to the regional differences between survey locations in the eastern slopes of the Judean Desert and the Central Negev (northern and southern sampling locations in Fig. 1, respectively). The basins of the Judean Desert are relatively small, narrow, steep, and flow along a rainfall gradient from about $300-400 \mathrm{~mm} \mathrm{yr}^{-1}$ at their headwaters to $<100 \mathrm{~mm} \mathrm{yr}^{-1}$ at their lower parts. In addition, these basins' lithology consists of harder rock material and very shallow soil. On the other hand, the basin drainage areas of the central Negev are characteristically larger, have gentler slopes, and their annual rainfall spatial distribution have lower variability. In addition, their exposed lithology has a relatively larger proportion of softer formations.

The cross correlations among the basin characteristics and the cross sectional hydraulic parameters are examined in Table 3. Catchment area (P1) and rainfall index (P2) are well correlated with the discharge and the other cross sectional properties of the AFIG. To a lesser extent, the catchment relief (P5), mean catchment softness (P6), and mean catchment permeability (P7) also appear as associated with the cross sectional properties. The mean annual precipitation (P3) and average relief of the drainage area (P4) show correlation coefficients that are not significantly different than zero. Overall it is seen that the basin properties are better associated with the geometric cross sectional properties such as top width, and wetted perimeter. The correlations for the flowrelated properties (i.e., discharge and velocity) are weaker when considering the basins predictors. In low flow events surface roughness has a much larger impact on the flow since the roughness elements become progressively smaller with increasing depth of flow (Graf, 1988).

The correlation coefficients presented in Table 3 suggest that at least one of the predictors in the multiple regression analysis (presented in the next section) should be either P1 or P2. However, because of the high correlation between these predictors (Table 2), the selection of the optimal set of predictors should be further examined.
Next we evaluated the ability to associate the properties of the cross sections at the AFIG with the basins' properties used as predictors in a multiple regression analysis.

This regression analysis is focused on the discharge, top width $(W)$ and hydraulic depth $(H)$ at the AFIG cross sections. The top width and the hydraulic depth are cross sectional parameters that are often required for regional hydrologic applications such as the Geomorphologic Unit Hydrograph (Rodriguez-Iturbe and Valdes, 1979) and derivation of threshold runoff for regional flash flood guidance systems (Carpenter et al., 1999; Georgakakos, 2006).

About a quarter of the field survey cross sectional dataset (11 out of 42 sites), representing different catchment sizes and mean rainfall, were left aside to be used for independent validation, while the remaining of the record was used for the multiple regression analysis. The analysis was conducted for the seven predictors and three predictands (i.e., discharge, width, and hydraulic depth), in linear and log scales, by evaluating different functional relationships such as linear, power law and exponential. The fit between the regression estimate and the observed variables were examined using a set of performance indices: Pearson correlation coefficient, multiplicative bias, nonparametric Spearman rank correlation coefficient, and Nash-Sutcliff (NS) efficiently index. Scatter plots for visual assessment of the quality of the fit were also examined.

The performance indices are presented in Table 4 for the calibration and validation datasets of the selected regressions. The resulting regression equations that were derived from the complete dataset (i.e., calibration and validation datasets) are presented in the right column of Table 4. We used the entire dataset for the derivation of these final regressions in order to utilize maximal information.

The selected regression for the discharge at the AFIG relies on the drainage area (P1) and basin averaged softness index (P6) as the preferred combination of predictors. On the other hand, for the top width and hydraulic depth at the AFIG 
Table 4. Performance evaluation and regression equations for AFIG discharge, top width and Hydraulic depth.

\begin{tabular}{|c|c|c|c|c|c|c|c|c|c|}
\hline \multirow[b]{2}{*}{ Predictant } & \multicolumn{2}{|c|}{ Pearson Cor. } & \multicolumn{2}{|c|}{ Multiplicative Bias } & \multicolumn{2}{|c|}{ Spearman Cor. } & \multicolumn{2}{|c|}{ NS } & \multirow[b]{2}{*}{ Equation } \\
\hline & Cal. & Val. & Cal. & Val. & Cal. & Val. & Cal. & Val. & \\
\hline AFIG discharge $\left(\mathrm{m}^{3} \mathrm{~s}^{-1}\right)$ & 0.89 & 0.93 & 0.76 & 0.62 & 0.65 & 0.56 & 0.74 & 0.75 & $Q=0.012 \cdot 1.003^{\mathrm{P} 1} \cdot 3.693^{\mathrm{P} 6}$ \\
\hline Top width (m) & 0.83 & 0.8 & 0.94 & 0.94 & 0.76 & 0.65 & 0.67 & 0.57 & $W=2.391 \mathrm{P} 1^{0.281}$ \\
\hline Hydraulic depth (m) & 0.41 & 0.82 & 0.95 & 0.85 & 0.25 & 0.58 & 0.14 & 0.38 & $H=0.114 \mathrm{P} 1^{0.134}$ \\
\hline
\end{tabular}

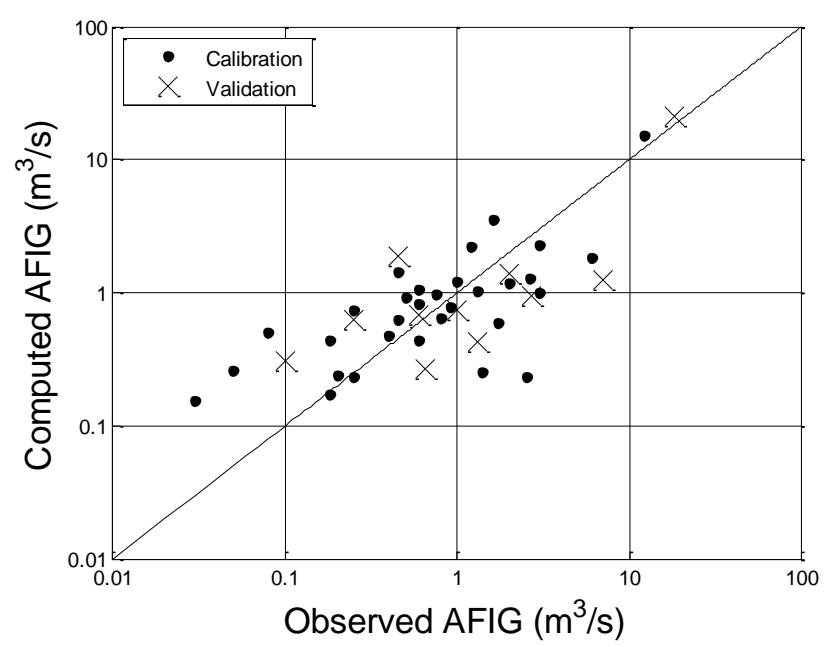

Fig. 7. Observed versus computed discharge values for the calibration and validation datasets (note the final equations presented in Table 4 were derived from the full dataset). The $1: 1$ line is shown.

cross section, the drainage area was found sufficient as a sole predictor (Table 4).

We note that the selection of preferred regression using multiple performance indices was rather subjective and included a suite of considerations: (a) the association between the predictors and the predictand should be physically reasonable and explainable, (b) the selected regression should be parsimonious and easily transferrable to be used in other regions, and (c) additional descriptors in the regression function should be assessed as a tradeoff between added value and added complexity to the regression.

The performance indices for a regression, which used drainage area as a sole predictor for the discharge at the AFIG, yield comparable performance indices values to the selected regression (Table 3). However, they are compromised by a spurious effect and only describe well the flow values that are $>\sim 5 \mathrm{~m}^{3} \mathrm{~s}^{-1}$ (not shown). It is only by adding the softness index as the second predictor that the regression function has monotonic increase that describes well the entire range of flow values (Fig. 7).

Identifying the basin area as a regression predictor for the AFIG properties is an expected result. Although, many of the low flow events are caused by local rain cells and during these events only a portion of the drainage area produces runoff, the channel cross sections in the basins outlet are

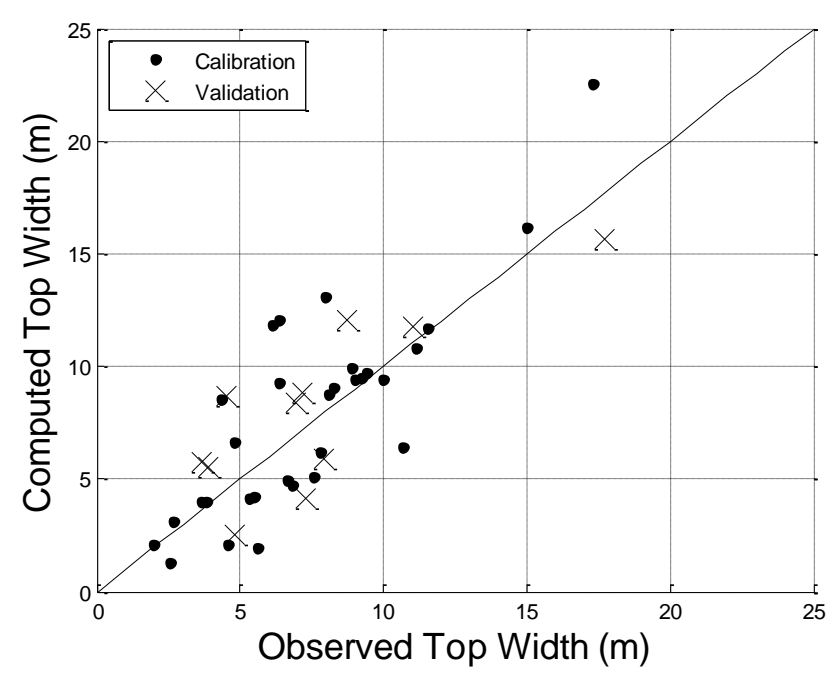

Fig. 8. Observed versus computed top width values for the calibration and validation datasets. The $1: 1$ line is shown.

tightly associated with the effective discharge. As discussed in Sect. 2, above, in arid climate the effective discharge is attributed to infrequent large events that likely are to cover the entire basin's drainage area.

The identification of the softness index as the second predictor was not anticipated. The discharge at the cross sections might occur either because of continuous flow that is caused by a basin wide rainfall event with streamflow that is conveyed downstream along the channel; or a discontinuous flow that is caused by local rainfall over contributing areas close to the stream banks. Since the discharge at the AFIG concerns very low flow events, it is reasonable to assume that most flows belong to the latter discontinuous cases. A possible explanation for the softness index being selected as a second predictor is that the relatively large areas of hard bare rocks near the channel banks upstream of the cross section produce runoff with relatively short flow distance over the hillslope to the channel and to the examined cross sections. In addition, as mentioned above, the velocity component of the discharge estimate is mainly dependent on local properties at the cross section such as the channel roughness and local slope. These might be better represented by the lithological softness index that characterizes in general the contributed lithology to the surveyed reach. Understanding the effect of the lithology on the discharge at the AFIG warrants additional investigation which is beyond the scope of this study. 
Table 5. Summary of data from the hydrometric stations that are collocated with surveyed cross sections.

\begin{tabular}{|c|c|c|c|c|c|c|}
\hline Name & Station ID & Years $^{\mathrm{a}}$ & Area $\left(\mathrm{km}^{2}\right)^{\mathrm{b}}$ & $\begin{array}{l}\text { Number of } \\
\text { flow events }\end{array}$ & $\begin{array}{r}\text { QAFIG } \\
\left(\mathrm{m}^{3} \mathrm{~s}^{-1}\right)^{\mathrm{d}}\end{array}$ & $\begin{array}{l}\text { QAFIG } \\
\text { Ascending Rank }\end{array}$ \\
\hline Lavan & 25191 & 24 & 207 & 48 & 0.18 & $0^{\mathrm{f}}$ \\
\hline Darga & 48125 & 18 & 75 & 27 & 0.25 & $0^{\mathrm{f}}$ \\
\hline Tkoa & 48130 & 18 & 139 & 36 & 2 & 9 \\
\hline Upper Zin & 55106 & 24 & 135 & 31 & 0.6 & $0^{\mathrm{f}}$ \\
\hline Zin waterfall & 55110 & 55 & 234 & 81 & 1 & 5 \\
\hline Mashosh & 55140 & 23 & 674 & 33 & 1.6 & 3 \\
\hline Ramon & 56140 & 26 & 111 & 48 & 0.25 & $0^{\mathrm{f}}$ \\
\hline
\end{tabular}

${ }^{a}$ Number of years available in the station's dataset; ${ }^{b}$ drainage area; ${ }^{c}$ number of flow events that were available from the station's record; ${ }^{\mathrm{d}}$ estimated discharge at the AFIG; ${ }^{\mathrm{e}}$ the AFIG discharge position in the ascending order of the station's discharge record.

${ }^{\mathrm{f}}$ Estimated flow at the AFIG is below the lowest flow event that was recorded at the hydrometric station.

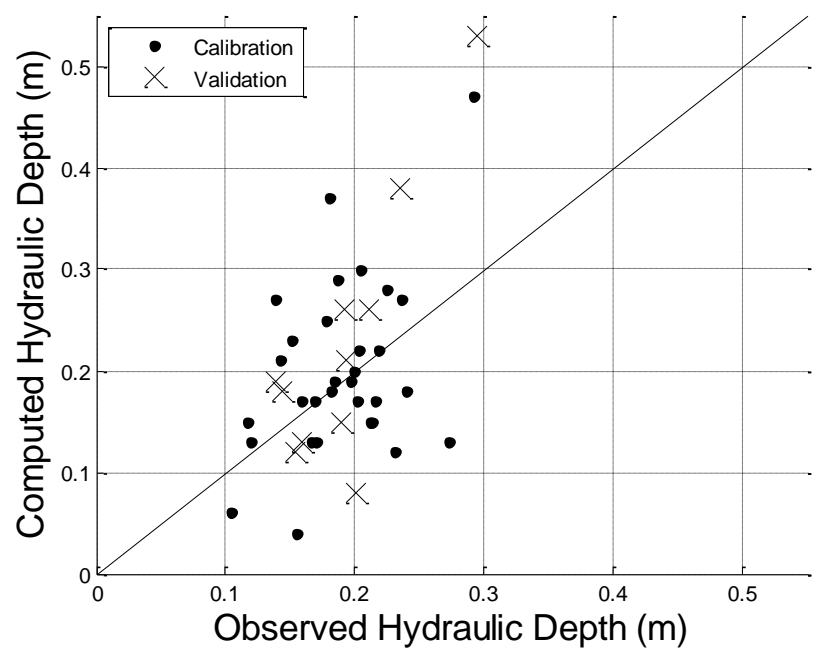

Fig. 9. Observed versus computed hydraulic depth values for the calibration and validation datasets. The $1: 1$ line is shown.

The computed discharge, top width, and hydraulic depth at the AFIG using the equations in Table 4 as a function of the observed variable are shown in Figs. 7, 8 and 9, respectively. For the discharge and the top width there is a reasonable monotonic relationship match between the regression output and the observed variables. In the case of the hydraulic depth (Fig. 9), the relationship appears weaker as also seen in Table 4. Other studies that are concerned with hydraulic depth at bankfull also showed relatively weaker regional association with the basin properties. For instance, Carpenter et al. (1999) reported that the regressions that were developed to calculate the hydraulic depth at bankfull using drainage area as a sole predictor explained $50 \%$ and $40 \%$ of the variability in Iowa and Oklahoma, respectively. On the other hand, a regression for top width at bankfull using drainage area as a predictor explained $91 \%$ and $82 \%$ of the variability for Iowa and Oklahoma, respectively. In our field survey the range of depth for the AFIG is $10-67 \mathrm{~cm}$. This relatively small range for the depth values is probably within the range of accuracy

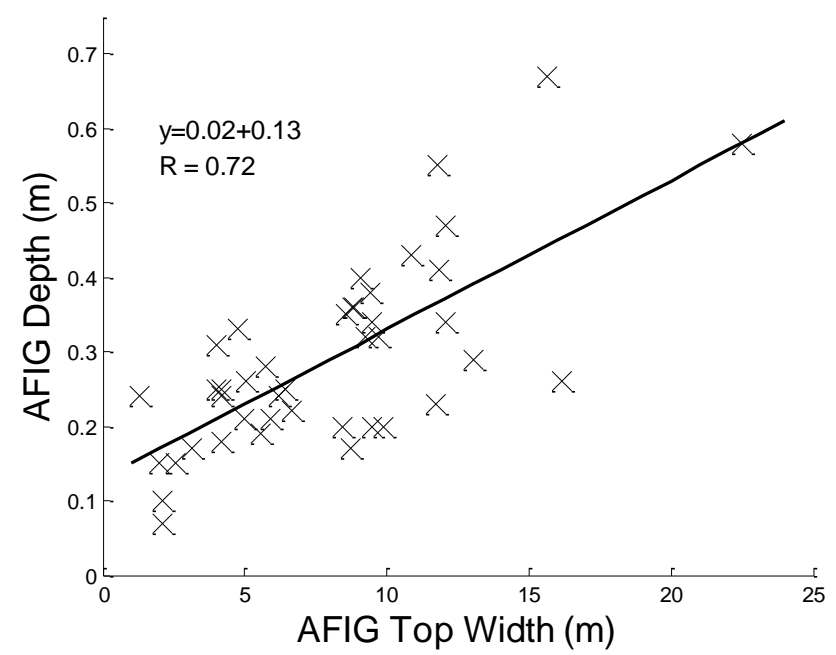

Fig. 10. Surveyed relationships between top width and depth at the AFIG. Solid black line indicates a linear regression fit.

expected during a field survey. Figure 2, for example, indicates that although the indices are clearly visible and distinguishable, an accurate measurement of their depth might be difficult to obtain.

The depth of the AFIG seems to be tightly associated with the top width (Fig. 10) which implies that depth is monotonically increasing with top width. This association between depth and width suggests that considering the shape of the cross sections as a trapezoid is a reasonable assumption.

\section{Frequency analysis}

The frequency of AFIG flow was assessed using historical discharge records from seven hydrometric stations that are co-located with surveyed cross sections (Table 5). In four of the hydrometric stations the calculated flow rate at the AFIG is smaller than the minimum recorded discharge of the station and is likely to be smaller than the detection level of the installed instrumentation at these stations. In the other 
Table A1. Basin characteristics as described in Sect. 6.

\begin{tabular}{|c|c|c|c|c|c|c|c|}
\hline $\begin{array}{l}\text { Wadi } \\
\text { name }\end{array}$ & $\begin{array}{r}\text { Area } \\
\left(\mathrm{km}^{2}\right)\end{array}$ & $\begin{array}{r}\text { Rain } \\
\text { Index } \\
\left(10^{6}\right. \\
\left.\mathrm{m}^{3} \mathrm{yr}^{-1}\right)\end{array}$ & $\begin{array}{r}\text { Mean areal } \\
\text { rainfall } \\
\left(\mathrm{mm} \mathrm{yr}^{-1}\right)\end{array}$ & $\begin{array}{r}\text { Mean basin } \\
\text { relief } \\
(\mathrm{m})\end{array}$ & $\begin{array}{r}\text { Range of } \\
\text { basin relief } \\
(\mathrm{m})\end{array}$ & $\begin{array}{r}\text { Mean basin } \\
\text { lithology }\end{array}$ & $\begin{array}{l}\text { Mean basin } \\
\text { permeability }\end{array}$ \\
\hline Lot & 0.5 & 0.054 & 100.0 & 49.52 & 44.5 & 2.86 & 1.87 \\
\hline Holed & 1.2 & 0.25 & 200.0 & 14.4 & 101.2 & 2.30 & 1.30 \\
\hline Yishay & 1.5 & 0.15 & 100.0 & 50.5 & 76.3 & 2.04 & 1.04 \\
\hline David & 4.4 & 0.61 & 138.8 & 59.5 & 102.8 & 2.31 & 1.31 \\
\hline Kedem & 4.5 & 0.70 & 156.7 & 65.1 & 101.4 & 2.73 & 1.73 \\
\hline Mishmar & 5.3 & 1.06 & 200.0 & 45.5 & 90.5 & 3.02 & 2.02 \\
\hline Parsa & 5.6 & 0.56 & 100.0 & 53.84 & 96.2 & 3.14 & 1.90 \\
\hline Hazazon & 8.3 & 1.66 & 199.4 & 54.2 & 82.2 & 4.00 & 2.99 \\
\hline Bokek & 9.5 & 0.95 & 100.0 & 53.69 & 72.3 & 3.84 & 2.04 \\
\hline Havarim & 9.9 & 0.99 & 100.0 & 47.2 & 160.3 & 1.93 & 1.82 \\
\hline Lavan & 12.0 & 1.20 & 100.0 & 60.6 & 141.3 & 2.46 & 1.74 \\
\hline Yeelim & 12.2 & 1.22 & 100.0 & 68.26 & 116.3 & 3.63 & 2.02 \\
\hline Kumeran & 17.4 & 3.37 & 193.31 & 57.89 & 188.7 & 2.23 & 1.56 \\
\hline Hever & 18.2 & 5.63 & 308.79 & 62.75 & 92.7 & 3.58 & 2.58 \\
\hline $\mathrm{Og}$ & 19.3 & 8.52 & 441.2 & 100.8 & 147.3 & 2.77 & 1.80 \\
\hline Kumeran & 20.9 & 3.67 & 175.84 & 58.4 & 168.1 & 2.31 & 1.70 \\
\hline Yeelim & 28.5 & 2.85 & 100 & 63.6 & 119.7 & 3.50 & 2.01 \\
\hline Hazazon & 32.2 & 6.92 & 214.7 & 56.7 & 119 & 3.77 & 2.72 \\
\hline Arugot & 32.3 & 11.65 & 360.4 & 82.3 & 191.8 & 2.92 & 1.92 \\
\hline Hever & 37.5 & 14.58 & 389.03 & 72.1 & 147.3 & 3.34 & 2.38 \\
\hline Hever & 41.6 & 11.23 & 270.25 & 55.6 & 108 & 3.23 & 2.23 \\
\hline Kumeran & 44.6 & 7.99 & 179.12 & 60.1 & 265.3 & 2.27 & 1.58 \\
\hline Adasha & 48.9 & 12.52 & 256.2 & 69.68 & 143.5 & 3.23 & 2.52 \\
\hline Darga & 51.9 & 20.47 & 394.23 & 80.91 & 176.5 & 2.97 & 1.94 \\
\hline Hatira & 60.2 & 7.05 & 117.0 & 53.1 & 180.1 & 2.61 & 2.09 \\
\hline Hatira & 66.1 & 7.85 & 118.78 & 63.1 & 226.2 & 2.91 & 1.94 \\
\hline Darga & 70.9 & 24.3 & 342.45 & 79.97 & 176.5 & 2.86 & 1.82 \\
\hline Hemar & 72.3 & 7.23 & 100.0 & 33.9 & 152 & 2.11 & 2.07 \\
\hline Zeelim & 75.9 & 16.71 & 220.1 & 43.16 & 167.2 & 3.03 & 2.68 \\
\hline Rahaf & 81.9 & 10.42 & 127.1 & 75.83 & 237.4 & 3.21 & 2.34 \\
\hline Hever & 99.0 & 34.35 & 347.1 & 61.65 & 154.2 & 3.42 & 2.44 \\
\hline $\mathrm{Og}$ & 105.9 & 39.00 & 368.3 & 83.8 & 166.4 & 3.12 & 2.16 \\
\hline Neqarot & 111.2 & 11.12 & 100.0 & 63.7 & 258.9 & 2.91 & 1.91 \\
\hline Zin & 122.4 & 12.24 & 100.0 & 39.1 & 193.3 & 2.96 & 2.17 \\
\hline Tekoa & 130.3 & 50.97 & 391.14 & 79.78 & 214.4 & 3.22 & 2.14 \\
\hline Arugot & 160.8 & 80.70 & 502.0 & 82.2 & 282.2 & 3.63 & 2.62 \\
\hline Lavan & 203.5 & 20.35 & 100.0 & 37.1 & 171.1 & 2.29 & 1.80 \\
\hline Darga & 230.0 & 79.73 & 346.7 & 84.5 & 402.5 & 3.02 & 1.96 \\
\hline Zin & 238.3 & 23.83 & 100.0 & 36.4 & 193.3 & 2.98 & 2.09 \\
\hline Hatira & 269.5 & 29.21 & 108.4 & 56.3 & 328 & 2.78 & 2.13 \\
\hline Hemar & 352.7 & 41.56 & 117.8 & 59.1 & 335.9 & 3.00 & 2.36 \\
\hline Neqarot & 379.9 & 37.99 & 100.0 & 54.1 & 316.3 & 3.20 & 2.20 \\
\hline Zin & 686.7 & 69.51 & 101.2 & 48.0 & 295 & 2.79 & 2.05 \\
\hline Neqarot & 723.3 & 64.48 & 89.15 & 56.5 & 316.3 & 3.18 & 2.38 \\
\hline Zin & 1132.5 & 115.35 & 101.9 & 50.9 & 328.2 & 2.87 & 2.14 \\
\hline Zin & 1228.7 & 124.83 & 101.6 & 54.4 & 367.6 & 2.90 & 2.17 \\
\hline
\end{tabular}


Table A2. Cross sectional properties of the AFIG.

\begin{tabular}{|c|c|c|c|c|c|c|c|c|c|}
\hline $\begin{array}{l}\text { Wadi } \\
\text { Name }\end{array}$ & $\begin{array}{r}\text { Mean } \\
\text { Flow } \\
\left(\mathrm{m}^{3} \mathrm{~s}^{-1}\right)\end{array}$ & $\begin{array}{r}\text { Max. } \\
\text { Depth } \\
\text { (m) }\end{array}$ & $\begin{array}{r}\text { Width } \\
(\mathrm{m})\end{array}$ & $\begin{array}{r}\text { Flow } \\
\text { Vel. } \\
\left(\mathrm{m} \mathrm{s}^{-1}\right)\end{array}$ & $\begin{array}{l}\text { Flow } \\
\text { Area } \\
\left(\mathrm{m}^{2}\right)\end{array}$ & $\begin{array}{r}\text { Hydraulic } \\
\text { Depth } \\
(\mathrm{m})\end{array}$ & $\begin{array}{r}\text { Wetted } \\
\text { Perimeter } \\
(\mathrm{m})\end{array}$ & $\begin{array}{r}\text { Channel } \\
\text { Slope } \\
\text { (fraction) }\end{array}$ & Channel bed \\
\hline Lot & 0.08 & 0.1 & 2.1 & 0.6 & 0.13 & 0.06 & 2.1 & 0.03 & Alluvial \\
\hline Holed & 0.20 & 0.24 & 1.3 & 1.0 & 0.19 & 0.15 & 1.5 & 0.02 & Alluvial \\
\hline Yishay & 0.18 & 0.17 & 3.2 & 0.5 & 0.38 & 0.13 & 3.0 & 0.02 & Alluvial \\
\hline David & 1.40 & 0.31 & 4.0 & 1.3 & 1.09 & 0.27 & 4.3 & 0.013 & Alluvial \\
\hline Kedem & 1.30 & 0.28 & 5.8 & 1.4 & 1.12 & 0.19 & 5.9 & 0.016 & Alluvial \\
\hline Mishmar & 0.45 & 0.25 & 4.0 & 0.6 & 0.83 & 0.21 & 4.2 & 0.013 & Alluvial \\
\hline Parsa & 1.00 & 0.19 & 5.6 & 1.1 & 1.02 & 0.18 & 5.7 & 0.017 & Alluvial \\
\hline Hazazon & 3.00 & 0.35 & 8.6 & 1.4 & 2.01 & 0.23 & 8.7 & 0.021 & Alluvial \\
\hline Bokek & 0.45 & 0.17 & 8.7 & 0.4 & 1.03 & 0.12 & 8.8 & 0.01 & Alluvial \\
\hline Havarim & 0.03 & 0.07 & 2.1 & 0.4 & 0.08 & 0.04 & 2.1 & 0.018 & Alluvial \\
\hline Lavan & 0.10 & 0.15 & 2.6 & 0.3 & 0.34 & 0.13 & 2.7 & 0.006 & Alluvial \\
\hline Yeelim & 0.45 & 0.22 & 6.7 & 0.5 & 1.11 & 0.17 & 6.7 & 0.02 & Alluvial \\
\hline Kumeran & 0.25 & 0.18 & 4.2 & 0.5 & 0.54 & 0.13 & 4.2 & 0.007 & Alluvial \\
\hline Hever & \multicolumn{8}{|c|}{ No low water line was found } & Bedrock/ Alluvial \\
\hline $\mathrm{Og}$ & 0.4 & 0.24 & 4.2 & 0.6 & 0.72 & 0.17 & 4.4 & 0.013 & Alluvial \\
\hline Kumeran & 0.05 & 0.15 & 2.0 & 0.4 & 0.26 & 0.13 & 2.1 & 0.014 & Alluvial \\
\hline Yeelim & 2.6 & 0.41 & 11.9 & 0.9 & 3 & 0.25 & 12.1 & 0.009 & Alluvial \\
\hline Hazazon & 6.0 & 0.47 & 12.1 & 1.4 & 4.28 & 0.37 & 11.9 & 0.018 & Alluvial \\
\hline Arugot & 1.7 & 0.32 & 9.3 & 1.0 & 1.63 & 0.18 & 9.4 & 0.018 & Alluvial \\
\hline Hever & 0.6 & 0.21 & 5.0 & 0.7 & 0.96 & 0.19 & 5.2 & 0.009 & Alluvial \\
\hline Hever & 0.5 & 0.33 & 4.7 & 0.4 & 1.37 & 0.29 & 5.0 & 0.001 & Alluvial \\
\hline Kumeran & 0.65 & 0.2 & 8.4 & 0.5 & 1.29 & 0.15 & 8.5 & 0.014 & Alluvial \\
\hline Adasha & 2.7 & 0.36 & 8.9 & 1.2 & 2.33 & 0.26 & 9.0 & 0.01 & Alluvial \\
\hline Darga & 0.6 & 0.25 & 4.2 & 0.7 & 0.87 & 0.21 & 4.3 & 0.013 & Alluvial \\
\hline Hatira & 0.6 & 0.26 & 5.1 & 0.6 & 0.95 & 0.19 & 5.1 & 0.006 & Alluvial/Sand \\
\hline Hatira & 0.8 & 0.24 & 6.2 & 0.6 & 1.26 & 0.2 & 6.3 & 0.005 & Alluvial \\
\hline Darga & 0.3 & 0.21 & 5.9 & 0.5 & 0.46 & 0.08 & 6.0 & 0.008 & Alluvial \\
\hline Hemar & 2.5 & 0.29 & 13.1 & 1.1 & 2.25 & 0.17 & 13.3 & 0.011 & Sandy \\
\hline Zeelim & 0.9 & 0.36 & 8.8 & 0.5 & 1.97 & 0.22 & 9.0 & 0.013 & Alluvial \\
\hline Rahaf & 3.0 & 0.4 & 9.1 & 1.1 & 2.7 & 0.3 & 9.2 & 0.007 & Bedrock/ Alluvial \\
\hline Hever & 2.0 & 0.34 & 12.1 & 0.6 & 3.11 & 0.26 & 12.2 & 0.011 & Alluvial \\
\hline $\mathrm{Og}$ & 0.8 & 0.2 & 9.9 & 0.5 & 1.48 & 0.15 & 10.1 & 0.019 & Bedrock/ Alluvial \\
\hline Neqarot & 0.3 & 0.2 & 9.5 & 0.2 & 1.37 & 0.15 & 9.5 & 0.001 & Alluvial \\
\hline Zin & 0.6 & 0.340 & 9.5 & 0.4 & 1.62 & 0.17 & 9.5 & 0.004 & Alluvial \\
\hline Tekoa & 2.0 & 0.32 & 9.7 & 1.0 & 2.1 & 0.22 & 10.0 & 0.02 & Bedrock \\
\hline Arugot & 1.2 & 0.38 & 9.4 & 0.5 & 2.63 & 0.28 & 9.6 & 0.003 & Alluvial \\
\hline Lavan & 0.2 & 0.25 & 6.4 & 0.2 & 0.8 & 0.12 & 6.6 & 0.001 & Alluvial \\
\hline Darga & 7.0 & 0.55 & 11.8 & 1.6 & 4.5 & 0.38 & 11.9 & 0.013 & Alluvial \\
\hline Zin & 1.0 & 0.43 & 10.9 & 0.3 & 2.95 & 0.27 & 11.0 & 0.003 & Bedrock \\
\hline Hatira & 1.3 & 0.23 & 11.7 & 0.6 & 2.14 & 0.18 & 11.8 & 0.007 & Alluvial \\
\hline Hemar & \multicolumn{8}{|c|}{ No low water line was found } & Alluvial \\
\hline Neqarot & \multicolumn{8}{|c|}{ No low water line was found } & Alluvial \\
\hline Zin & 1.6 & 0.26 & 16.1 & 0.8 & 2.14 & 0.13 & 16.2 & 0.012 & Alluvial \\
\hline Neqarot & \multicolumn{8}{|c|}{ No low water line was found } & Alluvial \\
\hline Zin & 12 & 0.58 & 22.6 & 1.1 & 10.67 & 0.47 & 22.8 & 0.006 & Alluvial \\
\hline Zin & 18 & 0.67 & 15.6 & 2.2 & 8.3 & 0.53 & 15.9 & 0.004 & Alluvial \\
\hline
\end{tabular}


three stations the AFIG flow rate was very close to the lowest recorded level of flows. The average occurrences of events that were registered in the stations are about 1.6 flows per year. This indicates that the return period of the flow at the AFIG is $<0.5$. This implies that the AFIG flow occurred on average at least twice a year.

\section{Concluding remarks}

This study is concerned with identifying a field-based geomorphic index that signifies low flows in ephemeral arid environments. It is motivated by a critical need for operational flood warning and asks "what is the minimal flow to be concerned about when a warning is needed?". In arid areas of Israel, as in other arid environments, the characteristics of floods are considerably different from perennial streams in temperate environments. Regional flood warning systems developed in temperate regions require extensive adaptation of concepts before they are applied in arid environments. For example, in temperate lowland regions, the concerning flood is often when the water level rises above the channel banks and inundates the floodplain along the entire river. In arid environments there are many cases when even the largest flows do not overflow the channel's sometimes undefined banks. Furthermore, planners in arid environments indicate that even the occurrence of low flow in the channel might already be considered as requiring warning.

We investigated the existence of a geomorphic index that represents initial low flow in alluvial ephemeral streams (wadis) of the arid and semi-arid zones of Israel. A comprehensive field survey was conducted and data were collected from 46 channel cross sections with drainage area ranging from 0.5 to $1230 \mathrm{~km}^{2}$. In most of the surveyed alluvial cross sections, a low flow index was clearly identifiable on the channel banks by the lowest vegetation line, a scour, or a change in pebble size. The characteristics of the cross section at this index level, which we termed Alluvial wadi Flooding Incipient Geomorphological index (AFIG), were associated with the contributing drainage area and basin-scale softness index based on the lithology exposed in the drainage basin. The flow at the AFIG appears to be a minimal flow that corresponds with the observation detection limit at the hydrometric stations, i.e., many low flows are missing in the records of these hydrologic stations.

Although large uncertainties are attributed to the survey results and the regression analysis, it is encouraging that such procedures were able to detect in the field an AFIG. Obviously, this specific index should be further investigated and validated within the framework of its use in prediction of flows in arid areas. The AFIG can potentially serve in unsurveyed locations as a threshold parameter for regional flash flood guidance models in arid environments. We plan to further investigate this concept to better understand its geomorphologic and hydrologic properties. In addition, we plan to extend the empirical studies to include ephemeral streams in various arid regions and develop nuances that reflect their specific traits.

Acknowledgements. This research was supported by the IsraelUSA Bi-National Science Foundation (BSF-2008046). The authors wish to thank Martin Teal, West Consultants Inc, for his valuable suggestions with respect to the HEC-RAS analysis, the Israeli Hydrological Service for streamflow data, Theresa Modrick from the Hydrologic Research Center, Gerard Benito and additional anonymous reviewer for their constructive comments.

Edited by: Y. Fan

\section{References}

Alexandrov, Y., Laronne, J. B., and Reid, I.: Suspended sediment concentration and its variation with water discharge in a dryland ephemeral channel, northern Negev, Israel, J. Arid Environ., 53, 73-84, 2003.

Baker, V. K.: Stream channel response to floods with examples from central Texas, Bull. Geol. Soc. Am., 88, 1057-1071, 1977.

Ben David-Novak, H., Morin, E., and Enzel, Y.: Modern extreme storms and the rainfall thresholds for initiating debris flows on the hyperarid western escarpment of the Dead Sea, Israel, Geol. Soc. Am. Bull., 116, 718-728. 2004.

Ben Moshe, L., Haviv, I., Enzel, Y., Zilberman, E., and Matmon, A.: Incision of alluvial channels in response to a continuous base level fall: Field characterization, modeling, and validation along the Dead Sea, Geomorphology, 93, 524-536, 2008.

Carpenter, T. M.: An interdisciplinary approach to characterize flash flood occurrence frequency for mountainous Southern California, Ph.D. Dissertation, University of California, San Diego, 2011.

Carpenter, T. M., Sperfslage, J. A., Georgakakos, K. P., Sweeney, T., and Fread, D. L.: National threshold runoff estimation utilizing GIS in support of operational flash flood warning systems, J. Hydrol., 224, 21-44, 1999.

Carpenter, T. M., Wang, J., Taylor, S. V., Shamir, E., Sperfslage, J. A., and Georgakakos, K. P.: Surveying flash flood response in mountain streams, EOS T. Am. Geophys. Un., 88, 69-72, 2007.

Coleman, D., MacRae, C., and Stein, E. D: Effect of increases in peak flows and imperviousness on the morphology of Southern California streams. A report from the Stormwater Monitoring Coalition, Technical Report 450, 2005.

Chow, V. T.: Open Channel Hydraulics, McGraw-Hill, New York, 1959.

Cooke, R. U., Warren, A., and Goudie, A. S.: Desert Geomorphology, University College London Press, London, 1993.

Dahan, O., Shani, Y., Enzel, Y., Yechieli, Y., and Yakirevich, A.: Direct measurements of floodwater infiltration into shallow alluvial aquifers. J. Hydrol., 344, 157-170, 2007.

Dayan, U. and Abramski, R.: Heavy rain in the Middle East related to unusual jet stream properties, B. Am. Meteorol. Soc., 64, 1138-1140, 1983.

Dayan, U. and Morin, E.: Flood-producing rainstorms over the Dead Sea basin, in: New Frontiers in Dead Sea Paleoenviron- 
mental Research, edited by: Enzel, Y., Agnon, A., and Stein, M., Geological Society of America, 53-62, 2006.

Dayan, U. and Sharon, D.: Meteorological parameters for discriminating between widespread and spotty storms in the Negev, Israel J. Earth Sci., 29, 253-256, 1980.

Dunkerley, D. and Brown, K.: Flow behavior, suspended sediment transport and transmission losses in a small (sub-bank-full) flow event in an Australian desert stream, Hydrol. Process., 13, 15771588, 1999.

Dury, G. H.: Magnitude frequency analysis and channel morphology, in: Fluvial Geomorphology SUNY Binghamton, edited by: Morisawa, M., Publications in Geomorphology, 91-121, 1973.

Emmett, W. W. and Wolman, M. G.: Effective discharge and gravelbed rivers, Earth Surf. Proc. Landforms, 26, 1369-1380, 2001.

Georgakakos, K. P.: Real-time flash flood prediction, J. Geophys. Res., 92, 9615-9629, 1987.

Georgakakos, K. P.: Analytical results for operational flash flood guidance, J. Hydrol., 317, 81-103, 2006.

Goodrich, D. C., Lane, L. J., Shillito, R. M., Miller, S. N., Syed, K. H., and Woolhiser, D. A.: Linearity of basin response as a function of scale in a semiarid watershed, Water Resour. Res., 33, 2951-2965, 1997.

Gomez, B., Coleman, S. E., Sy, V. W. K., Peacok, D. H., and Kent, M.: Channel change, bankfull and effective discharges on a vertically accreting, meandering, gravel-bed river, Earth Surf. Proc. Landforms, 32, 770-785, 2006.

Gordon, N. D., McMahon, T. A., Finlayson, B. L., Gippel, C. J., and Nathan, R. J.: Stream Hydrology: An Introduction for Ecologists, Wiley, 444 pp., 1992.

Graf, W. L.: Fluvial processes in Dryland rivers, Springer Series in Physical Environment, 346 pp., 1988.

Greenbaum, N., Ben-Zvi, A., Haviv, I., and Enzel, Y.: The hydrology and paleohydrology of tributaries to the Dead Sea, in: New Frontiers in Dead Sea Paleoenvironmental Research, edited by: Enzel, Y., Agnon, A., and Stein, M., Geological Society of America, 63-94, 2006.

Harman, C., Stewardson, M., and DeRose, R.: Variability and uncertainty in reach bankfull hydraulic geometry, J. Hydrol., 351, 13-25, 2008.

Harvey, A. M.: Channel capacity and the adjustment of streams to hydrologic regime, J. Hydrol., 8, 82-98, 1969.

Jensen, J. D.: Flood magnitude-frequency and lithologic control on bedrock river incision in post-orogenic terrain, Geomorphology, 82, 39-57, 2006.

Kahana, R., Ziv, B., Enzel, Y., and Dayan, U.: Synoptic climatology of major floods in the Negev Desert, Israel, Int. J. Climatol., 22, 867-882, 2002.

Kidron, J. G., Yair, A., Vonshak, A., and Abeliovitch, A.: Microbiotic crust control on runoff generation on sand dunes in the Negev desert, Water Resour. Res., 39, 1108, doi:10.1029/2002WR001561, 2003.

Kochel, R. C.: Geomorphic impact of large floods - review and new perspectives on magnitude and frequency, in: Flood Geomorphology, edited by: Baker, V. R., Kochel, R. C., and Patton, P. C., New York, NY: John Wiley \& Sons, 169-187, 1988.

Lange, O. L., Kidron, G. J., Budel, B., Meyer, A., Kilian, E., and Abeliovich, A.: Taxonomic composition and photosynthetic characteristics of the "biological soil crusts" covering sand dunes in the western Negev Desert, Funct. Ecol., 6, 519-527, 1992.
Laronne, J. B. and Reid, I.: Very high rates of bedload sediment transport by ephemeral desert rivers, Nature, 366, 148-150, 1993.

Leopold, L. B.: A View of the River, Harvard University Press, Cambridge, 298 pp., 1994.

Leopold, L. B., Wolman, M. G., and Miller, J. P.: Fluvial Processes in Geomorphology, W.H. Freeman and Co, San Francisco, 522 pp., 1964.

Lichvar, R. W. and McColley, S. M.: A Field Guide to the Identification of the Ordinary High Water Mark (OHWM) in the Arid West Region of the Western United States: A Delineation Manual, Cold Regions Research and Engineering Laboratory US Army Engineer Research and Development Center, Wetland Regulatory Assistance Program, 2008.

McEwen, L. J. and Werritty, A.: The hydrology and long term geomorphic significance of a flash flood in the Cairngorm mountains Scotland, Catena, 15, 361-377, 1988.

Meirovich, L., Ben-Zvi, A., Shentsis, I., and Yanovich, E.: Frequency and magnitude of runoff events in the arid Negev of Israel, J. Hydrol., 207, 204-219, 1998.

Moody, T., Wirtanen, M., and Yard, S. N.: Regional relationships for bankfull stage in natural channels of the arid southwest, Natural Channel Design Inc., Flagstaff, 38 pp., 2003.

Morin, E., Jacoby, Y., Navon, S., and Bet-Halachmi, E.: Towards flash-flood prediction in the dry Dead Sea region utilizing radar rainfall information, Adv. Water Resour., 32, 1066-0176, 2009a.

Morin, E., Grodek, T., Dahan, O., Benito, G., Kulls, C., Jacoby, Y., van Langenhove, G., Seely, M., and Enzel, Y.: Flood routing and alluvial aquifer recharge along the ephemeral arid Kuiseb River, Namibia, J. Hydrol., 368 262-275, 2009 b.

Mualem, Y. and Assouline, S.: Modeling rainfall-runoff relationship for bare soils affected by surface sealing, Catena supplement, 19 91-99, 1991.

Navratil, O., Herouin, M.-B. A. E., and Gressillon, J.-M.: Determination of bankfull discharge magnitude and frequency: comparison of methods on 16 gravel-bed streams, Earth Surf. Proc. Landforms, 31, 1345-1363, 2006.

Neff, E. L.: Discharge frequency compared to long term sediment yields, Publication International Association of Scientific Hydrology, 75, 236-242, 1967.

Pickup, G. and Rieger, W. A.: A conceptual model of the relationship between channel characteristics and discharge, Earth Surf. Proc. Landforms, 4, 37-42, 1979.

Pickup, G. and Warner, R. F.: Effect of hydrologic regime on magnitude and frequency of dominant discharge, J. Hydrol., 29, 51-75, 1976.

Phillips, J. D.: Geomorphic impacts of flash flooding in a forested headwater basin, J. Hydrol., 269, 236-250, 2002.

Phillips, J. V. and Tadayon, S.: Selection of Manning's roughness coefficient for natural and constructed vegetated and nonvegetated channels, and vegetation maintenance plan guidelines for vegetated channels in central Arizona: US Geological Survey Scientific Investigations Report 2006-5108, 41 pp., 2006.

Radecki-Pawlik, A.: Bankfull discharge in mountain streams: theory and practice, Earth Surf. Proc. Landforms, 27, 115-123, 2002.

Reid, I. and Frostick, L. E.: Channel form, flows and sediments in deserts, in: Arid Zone Geomorphology, edited by: Thommas, D. S. G., Willey Chickchester, 205-229, 1997. 
Reed, S., Johnson, D., and Sweeney, T.: Application and national geographic information system database to support two-year flood and threshold runoff estimates, J. Hydrol. Eng., 7, 209219, 2002.

Richards, K.: Rivers, form and process in alluvial channels, Mathuen \& Co., 361 pp., 1982.

Rodríguez-Iturbe, I. and Valdés, J. B.: The geomorphologic structure of hydrologic response, Water Resour. Res., 15, 1409-1420, doi:10.1029/WR015i006p01409, 1979.

Schick, A. P.: Formation and obliteration of desert stream terraces - a conceptual analysis, Z. Geomorphol., 21, 88-105, 1974.

Schick, A. P.: Hydrologic aspects of floods in hyper-arid environments, in: Flood Geomorphology, edited by: Baker, Y. R., Kochel, R. C., Patton, P. C., Wiley, New York, 12, 189-203, 1988.

Schick, A. P. and Sharon, D.: Geomorphology and climatology of arid watersheds. Department of Geography, Hebrew University, Jerusalem, 153 pp., 1974.

Schneider, C., Flörke, M., Eisner, S., and Voss, F.: Large scale modelling of bankfull flow: An example for Europe, J. Hydrol., 408, 235-245, 2011.

Schumm, S. A.: Effect of sediment characteristics on erosion and deposition in ephemeral stream channels, US Geological Survey Professional Paper 3520C, 31-70, 1961.

Schwartz, U.: Surface and near-surface responses to floods in a large channel (nahal zin) in the context of an alluvial aquifer in a hyper-arid environment, Ph.D. dissertation, Hebrew University of Jerusalem, 2001.

Sharon, D.: The spottiness of rainfall in desert area, J. Hydrol., 17, 161-175, 1972.

Shamir, E., Georgakakos, K. P., Spencer, C., Modrick, T. M., Murphy, M. J., and Jubach, R.: Evaluation of real-time flash flood forecasts for Haiti during the passage of Hurricane Tomas, 4-6 November 2010, Nat. Hazards, online first, doi:10.1007/s11069-013-0573-6, 2013.
Shentsis, I., Meirovich, L., Ben-Zvi, A., and Rosenthal, E.: Assessment of transmission losses and groundwater recharge from runoff events in a wadi under shortage of data on lateral inflow, Negev, Israel, Hydrol. Process., 13, 1649-1663, 1999.

Tooth, S.: Process, form and change in dryland rivers: a review of recent research, Earth Sci. Rev., 51, 67-107, 2000.

US Army Corps of Engineers: Accuracy of computed water surface profiles, Research Document 26, Hydrologic Engineering Center, Davis, CA, 1986.

US Army Corps of Engineers, Hec-Ras: water river analysis system, version 3.1.3, Davis, CA, 2005.

Warritty A.: Short term changes in channel stability, Chapter 3, in: Applied Fluvial Geomorphology for River Engineering and Management, edited by: Thorne, C. R., Hey, R. D., and Newson, M. D., John Willey and Sons, 1997.

Williams, G. P.: Bankfull discharge of rivers, Water Resour. Res., 14, 1141-1154, 1978.

Woodyer, K. D.: Bankfull frequency in rivers, J. Hydrol., 6, 114142, 1968.

Wolman, M. G. and Gerson, R.: Relative scales of time and effectiveness of climate in watershed geomorphology, Earth Surf. Proc., 3, 189-208, 1978.

Wolman, M. G. and Miller, J. P.: Magnitude and frequency of forces in geomorphic processes, J. Geol., 68, 54-74, 1960.

Yair, A. and Enzel, Y., The relationship between annual rainfall and sediment yield in arid and semi-arid areas. The case of the northern Negev, Catena supplement, 10, 122-136, 1987.

Yair, A. and Kossovsky, A.: Climate and surface properties: hydrological response of small arid and semiarid watersheds, Geomorphology, 42, 43-57, 2002. 